\title{
The Implementation of Beyond Centers and Circle Times (BCCT) in Early Childhood Education
}

\author{
Slamet Lestari \\ Educational Administration Department \\ Universitas Negeri Yogyakarta \\ Yogyakarta, Indonesia \\ slamet_lestari@uny.ac.id
}

\begin{abstract}
There are several aims of this study. First, is to describe the implementation of Beyond Centers and Circle Times (BCCT) at Rumah Ibu, an early childhood education institution in Yogyakarta. Second, is to investigate the constraints in the implementation of BCCT at Rumah Ibu. Third, is to examines the efforts to overcome the obstacles in implementation of BCCT at Rumah Ibu. The method used in the study is a qualitative study. The participants include the principal and the teachers of Rumah Ibu. Interviews, observations, and documentation were used as data collection techniques, while the interactive model become the method of the data analysis in this study. There are several results of this study. First, BCCT at Rumah Ibu is implemented in the contemporary style. This is different from the other early childhood learning institutions, which are conducting in the classical style. The implementation of BCCT at Rumah Ibu makes learning more meaningful and fun because of the learning method and setting which use several playing centers. Second, the constraints in the implementation of BCCT at Rumah Ibu consist of students' difficulties in adapting themselves to the learning patterns, the lack of facilities for BCCT implementation, and the lack of teachers' competencies for BCCT, especially the new teachers. Third, to overcome the obstacles in implementation of BCCT at Rumah Ibu, teachers need to give meaning and direction to students, to explore the natural environment, to make educative games equipment, and to participate in seminars, training, and internships.
\end{abstract}

Keywords-Learning Method, Early Childhood Education

\section{INTRODUCTION}

Early childhood is the "golden age" of child development. The researchers proved that 50 percent of human learning progress is determined in the first four years. And human being is formed another 30 percent before reaching eight years of age (Bloom, 1964). Similarly, the importance of this age require education which is appropriate with needs and characteristics so that early childhood can grow and develop optimally. Early childhood education is the foundation of physical growth, socioemotional aspect, language, and communication in accordance with the unique development of early childhood. To achieve these objectives specifically teaching methods should also be in accordance with characteristics of early childhood.

However, the current teaching methods applied in early childhood have been based on the early childhood learning menu reference. This condition is indicated by several things, such as educational practice which is still teachercentered and classical learning methods. This may be due to, among others, a lack of knowledge on the characteristics of the development of early childhood educators, so it makes the conception and practice for educating early childhood less appropriate.

One of the methods developed for early childhood learning today is Beyond Centers and Circle Time (BCCT). BCCT is an early childhood learning method that aims to stimulate all aspects of children's intelligence (multiple intelligence) through purposeful games activities (Florida Department of Education, 2007). BCCT method is clearly different and still rarely used in early childhood learning today. One of the early childhood education institutions that have implemented BCCT is Rumah Ibu. Its is an early childhood education institutions in Yogyakarta. However, because BCCT is still new there are still many things that need to be improved to be able to implement BCCT perfectly. BCCT implementation issues in early childhood education are very interesting to study. Therefore, this study is expected to provide an overview of information about the implementation BCCT in early childhood education.

\section{METHOD}

The method used in the study is a qualitative study. The participants includes the principal and the teachers of Rumah Ibu. Interviews, observations, and documentation were used as data collection techniques, while the interactive model become the method of the data analysis in this study.

\section{RESULT \& DISCUSSION}

Implementation of BCCT at Rumah Ibu includes three groups of activities, namely: preparation, implementation, 
and evaluation. Each of these activities will be described as follows.

\section{A. Preparation}

The principal, teachers, and staff members were prepared through a one-day seminar and through observations and internship for five days in An Nur Sleman. Through the seminar, the principal, teachers, and staff members gain knowledge about the concept of BCCT while internships provide practical experience of the implementation of BCCT. Places and educational toys are also prepared in accordance with the type of center that will be opened and the child's age level. Group administration and recording of children's development in the form of children's anecdoctal records also prepared administratively. Children's anecdoctal records is a record of a child's development, both positive and negative that appears in the games, for example, children memorized short Qur'anic chapters or suras while playing. During the learning process there are who tend to be silent. It is useful as an evaluation of the teacher so that there is no labeling "silent child" or a "bad boy". Parents are also prepared by the introduction of BCCT learning methods so that they do not protest and disturb their playing activities. Parents are introduced to each of the playing centers prepared for children to nuance themselves. Activities are carried out through two meetings forum. First meeting, at the initial meeting of the new school year. The meeting discussed a wide range of learning programs, learning support programs (nutrition park, outing, and parenting classes), and the school rules. Second meeting, when parenting class meeting which was held once every three months. Parenting class is a meeting for parents which contains the delivery of parenting materials (education, health, social and emotional development of the child). In the parenting class forum, the school bring in the speakers/experts, such as psychologists, pediatricians, and early childhood educators.

\section{B. Implementation}

At the time of the learning implementation, playing centers opened in stages, according to the readiness of teachers and other supporting facilities. Nowadays Rumah Ibu has five centers for the implementation of the BCCT method:

a. Worship centers, for stimulating and developing the spiritual intelligence of children through the ability to know and love God. Children can be stimulated gradually through cultivation of moral values and religion, introduction of praying ordinance, introduction of worship ritual. Learning facilities of the available include rukuh, prayer rugs, Iqro' books, Arabic card and puzzle, moslem magazine for early childhood education, Islamic posters, and so on.

b. Preparation centers, for stimulating and developing the linguistic and mathematical intelligence of children. Language intelligence developed through speaking, listening, singing, reciting, reading, writing, and telling a story. Mathematical intelligence is stimulated through activities of numbers recognizing, counting, shapes and colors diferentiating, data analyzing, and objects categorizing. Learning facilities of the available scissors, glue, paper folding, puzzles, marbles, tassel, rope, thematic picture cards, early childhood magazines, worksheets, pencils, markers, crayons, and so on.

c. Block centers, for stimulating the visual-spatial intelligence (visual field) development, children are stimulated through playing of block (recognizing of geometric shapes), puzzles, drawing, painting, watching movies, and playing with imagination. Learning facilities of the available include wooden block and various accessories.

d. Role playing centers, for stimulating interpersonal and intrapersonal intelligence of children through playing together, cooperation games, role playing, problem solving, and conflict solution. Learning facilities of the available include a mini kitchen tools, carpet, color block, profession equipment toys, hand puppets, wooden dolls, and so on.

e. Nature centers, for stimulating and developing the children intelligence through the use of materials that exist in the surrounding environment such as leaves, branch, sand, grain, grass, mud, clay, water, and so on. Children are playing with exploring of natural materials, creating, thinking, communicating, and soft and hard psychomotoric training. Learning facilities of the available include buckets, stone, gravel, sand, clay, flour playdogh, watercolor, charcoal, scissors, tables, waterproof, and so on.

Implementation of BCCT in the learning process at Rumah Ibu can be described as follows.

\section{1) Managing of playing environment}

Before the children were came, teachers prepare materials and games equipment to be used according to plan and schedule activities that have been arranged for groups of children were cultivated. Then, to arrange the games materials and equipment to be used in accordance with the guidance age group. This arrangement should reflect the learning plan that includes aspects that will be achieved in a learning theme, contains indicators appropriate of child development. This means, the objectives of the children during play with the play tool. For example, cognitive aspects of transportation theme to be achieved, one indicator is the child can draw a line (vertical, horizontal, and curved), that means at the preparation center, children activities are drawing bus with lines making method (vertical, horizontal, and curved).

\section{2) Welcoming children}

All the teachers as a duty welcoming a child (hello, smile, greet) unless the teachers as a duty of preparing the class centers. Children are directed to follow the morning journal, that every child is given a book to draw freely using various media (pencils, markers, crayons, pens). It is to know children condition on the day, for example, children drawing people who face's painted in red colour. After teachers apparently asked the child had just scolded his father. From the results of these early journals, teachers have been able to understand the condition of the child from the home. So that teachers can give direction to follow centers with stable emotions. 
3) Opening games (coarse motion experience)

Opening games activity takes approximately 30 minutes. Teachers prepare all children in a circle, then doing "Senam Sehat-Gembira", Islamic religious education (memorizing short Qur'anic chapters, Islamic songs and applause), toilet training, and a morning snack.

\section{4) Transition (10 minutes)}

Each study group marched at yard school following class teachers. Teachers provide rules and the consequences for the child before go to classes. In the classroom teachers briefed on the day's theme, the playing activities to be carried out by the children, rules, and consequences for at the center.

\section{5) Core activities in each group}

a) Footing of before playing experience (15 minutes)

Teacher invite children to sit in a circle and then to greet the children, ask about the children, who asked not present. Then prayed that led one of the children who were assigned in rotation. Teacher present the theme that will be studied on the day, for example by reading a book. The story asked back to the students, then linked to the main activities undertaken. Place and games equipment that has been prepared also introduced in children. Capability that is expected to appear in children as basis for giving a footing, according to the study plan that has been prepared. Also presented are the rules of the games, choose a playmate, choose the toys, how to use tools, when to start and end the games, and smoothed back a tool that has been played. In selecting playmate, teachers could also regulates playmate by allowing the child to choose his playmates. Or if there are children who simply choose a particular child as a playmate, should be offered to swap his playmates so that children can be more sociable. After the children are welcome to start playing, teachers help to organize the child does not scramble and more orderly, for example by rotating each child the opportunity to start playing.

\section{b) Footing of during playing experience (60 minutes)}

As long as the children playing, teachers around while observing and if there are children who can not use the materials should be an example of how to play, and give positive reinforcement for a job well done children and provide assistance to children in need. To expand the ways to play, the child can be lured with open-ended questions are questions that have many possible answers that can be given a child, so it is not enough to only be answered yes or no. Children should also be encouraged to try other ways so that children play experience richer. What they did note (kind of play, stages of development, social stage), the work of children gathered and recorded the name and date on the worksheet children. If the residence time of about five minutes, teachers gave the children to prepare for completing the activities.

\section{c) Footing of after playing experience (30 minutes)}

If the play time runs out, the children were told time to clean tools and materials used to engage them. If not used, make a game that stimulates the child to take care of. Teachers prepare a different place for each type of equipment so that children can group game tool in place. If it is orderly, teachers then took the child back to its original position sitting in a circle with teachers.

If all children had been sitting in a circle, the teachers asked back (recalling) the playing activities that have been performed on each child. It can train memory and train the children' bravery suggest ideas and game experience. Teachers ask children' favorite and unfavorite activities. It is useful for the evaluation of teachers more innovative in creating a variety of play activities for children. Ideally, the same amount of play activities with $1 / 2$ the number of children plus one, example the number of students acacia class there are six children, the playing activities that must be provided at each center teachers four play activities.

\section{6) Lunch}

The children gathered in the hall for lunch following along with learning to patiently wait their turn, for example marched to washing hands, knowing of eating etiquette, and clear the table independently.

\section{7) Closing activities (15 minutes)}

When finished eating, all the children pray after eating, children get ready to take wudlu and Dhuhr in the mosque, the other children do toilet training, washing face, and to the rest room for a nap. In the room, teacher giving storytelling (storytelling), then closed with a prayer to bed together.

\section{Evaluation}

\section{1) Program evaluation}

The program is evaluated to determine the effectiveness of early childhood programs that include:

- Teacher performance, through weekly meetings

- Administration of learning, through weekly meetings and quarterly reports of school programs that have been implemented. Incidentally, District Education Department also held frequent unannounced inspections.

\section{2) Children development progress evaluation}

Children's learning activities are recorded every meeting by noting the development of the child's ability in terms of gross motoric skills, fine motoric skills, language, social, and other aspects. Listing of play activities of children and child development by teachers can be done by looking at the children's work and child diary (children's anecdoctal records), and evaluation every three months (checklist), and progress reports (report cards).

\section{CONCLUSION}

BCCT at Rumah Ibu is implemented in the contemporary style. This is different from the other early childhood learning institutions which are conducting in the classical style. The implementation of BCCT at Rumah Ibu makes learning more meaningful and fun because of the learning method and setting which use several playing centers. Second, the constraints in the implementation of BCCT at Rumah Ibu consist of students' difficulties in adapting themselves to the learning patterns, the lack of 
facilities for BCCT implementation, and the lack of teachers' competencies for BCCT, especially the new teachers. Third, to overcome the obstacles in implementation of BCCT at Rumah Ibu, teachers need to give meaning and direction to students, to explore the natural environment, to make educative games equipment, and to participate in seminars, training, and internships.

\section{REFERENCES}

[1] Bloom, Benyamin S, Stability and Change in Human Characteristics, New York, John Wiley, 1964.

[2] Florida Department of Education, Beyond Centers \& Circle Time Pre-Kindergarten Theme Series: Introduction, Florida, Florida Department of Education, 2007. 